\title{
WYZWANIA I PRZEMIANY W KREOWANIU MODELI BIZNESOWYCH PRZEZ POLSKICH PRZEDSIĘBIORCÓW A PROCESY WZROSTU MAŁYCH I ŚREDNICH PRZEDSIĘBIORSTW
}

\begin{abstract}
Modele biznesowe są relatywnie nowym narzędziem intensywnie popularyzowanym zarówno w nauce, jak i praktyce gospodarczej przedsiębiorstw. Doświadczenia pokazują, iż stosowanie ich w zarządzaniu firmami, wpływa na wzrost i pozycję konkurencyjną podmiotów. Model biznesowy może być traktowany również jako narzędzie służące do kreowania nowych metod prowadzenia działalności gospodarczej, a tym samym do reorganizacji wewnętrznych procesów, poszukiwania nowatorskich sposobów sprzedaży lub komunikacji z klientami. W przypadku najmniejszych przedsiębiorstw model biznesowy kształtuje się jako całościowy system w sposób niemalże naturalny, głównie dzięki zaangażowaniu, pomysłowości i doświadczeniu samego przedsiębiorcy. Modele biznesowe traktowane są zatem jako proste w zastosowaniu narzędzia, pozwalające osiągać wymierne korzyści zarówno małym jak i większym przedsiębiorstwom. Ułatwiają podejmowanie strategicznych decyzji i wspomagają bieżące zarządzanie firmą. Pozwalają odnajdywać nisze rynkowe i wzmacniać pozycję konkurencyjną firmy poprzez m.in. dywersyfikację działalności, wchodzenie na nowe rynki, znajdywanie nowych zastosowań dla posiadanych produktów, optymalizację zarządzania dostępnymi zasobami i procesami itp. Modelowanie biznesu obejmuje definiowanie obszarów działalności przedsiębiorstwa począwszy od procesów wewnętrznych, a skończywszy na wartości dla klienta.

W artykule przeanalizowano szczególne cechy modeli biznesowych odnosząc je do wybranych przedsiębiorstw zaliczanych do grupy mikro-, małych i średnich, działających w specyficznym otoczeniu oraz w tzw. niszowych branżach. Autorki zaprezentowały nietypowe
\end{abstract}

\footnotetext{
${ }^{1}$ Dr inż. Adriana Kaszuba-Perz, Zakład Finansów, Bankowości i Rachunkowości, Wydział Zarządzania, Politechnika Rzeszowska im. I. Łukasiewicza, Al. Powstańców Warszawy 12, 35-959 Rzeszów, autor korespondencyjny; e-mail: aperz@prz.edu.pl.

Adriana Kaszuba-Perz, PhD Eng., Department of Finance, Banking and Accounting, Faculty of Management, Rzeszów University of Technology I. Łukasiewicz, Al. Powstańców Warszawy 12, 35-959 Rzeszów, correspondence author; e-mail: aperz@prz.edu.pl.

${ }^{2}$ Dr Marta Czyżewska, Katedra Ekonomii i Polityki Gospodarczej, Instytut Prawa, Administracji i Ekonomii, Wydział Politologii, Uniwersytet Pedagogiczny im. Komisji Edukacji Narodowej w Krakowie, ul. Podchorążych 2, 30-084 Kraków; e-mail: marta.czyzewska@up.krakow.pl.

Marta Czyżewska, PhD, Department of Economics and Economic Policy, Institute of Law, Administration and Economics, Faculty of Political Science, Pedagogical University National Education Commission in Krakow, ul. Podchorążych 2, 30-084 Kraków; e-mail: marta.czyzewska@up.krakow.pl.
} 
rozwiązania modeli biznesowych wykorzystywane przez przedsiębiorców dla przetrwania i wzrostu firmy.

Słowa kluczowe: małe i średnie przedsiębiorstwa, przedsiębiorczość, modele biznesowe, kreowanie wzrostu firmy.

\section{WPROWADZENIE}

Na przestrzeni ostatnich lat w naukach o zarządzaniu pojawiają się coraz to nowe koncepcje i narzędzia, które mają wspierać wzrost przedsiębiorstw. Znane są poglądy m.in. P. Druckera na temat identyfikacji szans, które odpowiednio wykorzystane stwarzają możliwość innowacyjnego prowadzenia biznesu i tym samym przyczyniają się do odnoszenia sukcesu i przetrwania na rynku ${ }^{3}$. Reinginering, zarządzanie procesowe, zarządzanie dokonaniami, lean management i wiele innych koncepcji niewątpliwie przyczyniło się zarówno do usprawnienia działalności przedsiębiorstw, jak i do ich wzrostu. W ciągu ostatnich lat szeroko omawiane są zagadnienia zintegrowanego zarządzania przedsiębiorstwem przy wykorzystaniu m.in. instrumentów controllingowych i technik informatycznych. Niezwykle dynamiczny rozwój technologii informatycznych i komunikacyjnych stanowi dla wielu przedsiębiorstw istotny przełom w ich działalności. Samo oprogramowanie komputerowe wspomagające zarządzanie, jak i komunikatory internetowe w znaczący sposób wpłynęły na rozwój przedsiębiorstw zarówno tych małych, średnich, jak i dużych. Koncepcja Business Intelligence, bazująca na przekonaniu, iż jakość informacji oraz metody jej przetwarzania, prezentowania i wykorzystania w przedsiębiorstwie stały się podstawą funkcjonowania współczesnych przedsiębiorstw w wysoko-konkurencyjnej przestrzeni gospodarczej $^{4}$. Wydaje się, że modelowanie biznesu obejmuje wszystkie te zagadnienia - poprzez definiowanie obszarów działalności przedsiębiorstwa począwszy od procesów wewnętrznych, a skończywszy na wartości dla klienta.

Wśród praktyków i teoretyków biznesu toczy się dyskusja, czy model biznesowy to pojęcie odnoszące się do architektury i procesów zachodzących w przedsiębiorstwie, a skoncentrowanych na budowaniu wartości i osiąganiu korzyści ekonomicznych, czy też może być traktowane szerzej jako filozofia prowadzenia działalności gospodarczej. Ponieważ koncepcja modelowania biznesu pojawia się zarówno u klasyków zarządzania i marketingu ${ }^{5}$, jak i wśród inżynierów IT - jednoznaczne zdefiniowanie tej kategorii wydaje się utrudnione. Zwłaszcza, że współczesne przedsiębiorstwa działające w warunkach wysokiej konkurencji, nastawione są często na ustawiczne poszukiwanie nowych rozwiązań w każdym z obszarów swojej działalności, w celu wypracowania skutecznych przewag konkurencyjnych.

${ }^{3}$ P.F. Drucker, Zarządzanie w czasach burzliwych. Warszawa 1995, s. 15.

${ }^{4}$ B. Wixom, H. Watson, The BI-based organization, ,International Journal of Business Intelligence Research" 2010, No. 1; J. Penc, Menedżer $w$ działaniu, t. 2: Podejmowanie najlepszych decyzji, Warszawa 2003, s. 224; A. Bytniewski (red.), Systemy informatyczne a rozwój spoteczeństwa informacyjnego, e-book Wydawnictwo Uniwersytetu Ekonomicznego we Wrocławiu 2015; A. Bytniewski, M. Hernes, Technologie informacyjne jako czynnik rozwoju nowych funkcjonalności zintegrowanych systemów zarządzania w ramach koncepcji big management, Studia Ekonomiczne. Zeszyty Naukowe Uniwersytetu Ekonomicznego w Katowicach nr 341/2017.

${ }^{5}$ M. Porter, What is Strategy?, „Harvard Business Review” November-December 1996; M. Porter, Strategy and the Internet, "Harvard Business Review" March 2001. 
Celem artykułu jest próba wskazania szczególnych cech modeli biznesowych dla podmiotów zaliczanych do grupy małych i średnich przedsiębiorstw, które działają w specyficznym otoczeniu. Zamierzeniem autorek jest prezentacja nietypowych rozwiązań wykorzystywanych przez przedsiębiorców dla przetrwania i wzrostu firmy.

\section{DEFINICJE MODELI BIZNESOWYCH}

W literaturze przedmiotu stworzono wiele definicji modeli biznesowych ${ }^{6}$. Jedną z najbardziej popularnych w ostatnich latach jest definicja modelu biznesowego zaproponowana przez A. Osterwaldera i Y. Pigneura ${ }^{7}$. Według autorów model biznesowy opisuje przesłanki stojące za sposobem, w jaki organizacja tworzy wartość oraz zapewnia i czerpie zyski z tej wytworzonej wartości. Wyodrębnili w modelu biznesowym następujące elementy:

1. segmenty klientów, które stanowią różne grupy ludzi i organizacje, do których przedsiębiorstwo stara się dotrzeć i które chce obsługiwać,

2. propozycja wartości to zbiór produktów i usług, które generują wartość dla konkretnego segmentu klientów,

3. kanały, czyli sposoby, w jaki firma komunikuje się z poszczególnymi segmentami swoich klientów i w jaki sposób przekazuje im swoją propozycję wartości,

6 J. Magretta, Why business models matter?, "Harvard Business Review", 2002, 80(5), s. 86-92; A.K. Koźmiński, Zarzadzanie w warunkach niepewności. Podręcznik dla zaawansowanych, Warszawa 2004, s. 123; R. Arend, The business model: Present and future - beyond a skeumorph, "Strategic Organisation" 2013, 11(4), s. 390-402; M.W. Johnson, Seizing the white space: Business model innovation for growth and renewal, Boston 2010, s. 22; Ch. Zott, R. Amit, The business model: A theoretically anchored robust construct for strategic analysis, "Strategic Organisation", 2013, Vol. 4, s. 403-411; D.J. Teece, Business model, business strategy and innovation, "Long Range Planning" 2010, Vol. 43, s. 192; M. Morris, M. Schindehutte, J. Allen, The entrepreneur's business model: toward a unified perspective, "Journal of Business Research" 2005, Vol. 58, s. 727; Ch. Zott, R. Amit, L. Massa, The business model: Recent developments and future research, "Journal of Management" 2011, Vol. 37, s. 2; R. Timmers, Business models for electronic markets, "Electronic Markets", 1998, 8(2), s. 2; A. Afuah, Ch.L. Tucci, Biznes internetowy - strategie I modele, Kraków 2003, s. 20; H. Chesbrough, R.S. Rosenbloom, The role of the business model in capturing value from innovation: evidence from XEROX Corporation's technology spin-off companies, "Industrial and Corporate Change" 2002, 11(3), s. 529; A. Osterwalder, Y. Pigneur, Tworzenie modeli biznesowych. Podręcznik wizjonera, Gliwice 2013, s. 19; S.M. Shafer, H.J. Smith, J.C. Linder, The power of research models, "Business Horizons" 2005, Vol. 48, s. 200; A.J. Slywotzky, D.J. Morisson, B. Andelman, Strefa zysku. Strategiczne modele działalności, Warszawa 2000, s. 26-28; J. Hedman, T. Kalling, The business model concept: theoretical underpinnings and empirical illustrations, "European Journal of Information Systems" 2010, Vol. 12, s. 52; Ch. Baden-Fuller., V. Mangematin, Business models: A challenging agenda, "Strategic Organisation" 2013, 11(4), s. 420; M.W. Johnson, C. Christensen, Reinventing your business model, "Harvard Business Review” 2008, 86(12), s. 3; 51-59; B. Demil, X. Lecocq, Business model evolution: In search of dynamic consistency, "Long Range Planning" 2010, Vol. 43, 231; B. de Wit, R. Meyer, Synteza strategii, Warszawa 2007, s. 112; M. Kardas, Pojęcia i typy modeli biznesu [w:] Zarzadzanie, organizacje i organizowanie - przeglad perspektyw teoretycznych, red. K. Klincewicz, Warszawa 2016, s. 298-19; K. Obłój, Tworzywa skutecznych strategii, Warszawa, 2002, s. 97.

7 A. Osterwalder, Y. Pigneur, Tworzenie modeli biznesowych. Podręcznik wizjonera, Gliwice 2013, s. 19-45. 
4. relacje z klientami, czyli charakterystyka relacji, jakie łączą firmę z przedstawicielami konkretnego segmentu klientów,

5. strumienie, czyli wartość przychodów generowanych przez firmę w związku z obsługą każdego z segmentów rynku,

6. kluczowe zasoby, tj. najważniejsze zasoby niezbędne do prawidłowego funkcjonowania podmiotu,

7. kluczowe działania, które firma musi podejmować, żeby jej model sprawnie funkcjonował,

8. kluczowi partnerzy, tj. sieć dostawców i współpracowników, od których zależy sprawne funkcjonowanie przedsiębiorstwa,

9. struktura kosztów - obejmuje wszystkie wydatki ponoszone w związku ze stosowaniem określonego modelu biznesowego.

Wspólne elementy będące rezultatem porównań szeregu definicji modelu biznesowego wskazała P. Bednarz ${ }^{8}$ wyodrębniając:

- sieć i jej struktura,

- transakcje,

- generowanie dochodu,

- wiedza.

M. Sagan podobnie wskazuje na:

- wartość (korzyści), którą zamierza zaoferować klientowi przedsiębiorstwo,

- ścisłe określenie grupy nabywców tej wartości oraz

- sposób utrzymania przewagi konkurencyjnej na rynku.

Model biznesu jest spojony przez zasoby oraz wyróżniające firmę zdolności ${ }^{9}$

\section{MODEL BIZNESOWY JAKO PODSTAWA FUNKCJONOWANIA BIZNESU I NARZEDZIE KREOWANIA WZROSTU PRZEDSIEBBIORSTWA}

Stworzenie modelu biznesowego jest punktem wyjścia w inicjowaniu, ale także rozwijaniu przedsiębiorstw. Funkcjonowanie na konkurencyjnym rynku zmusza przedsiębiorstwa do ciągłego weryfikowania stosowanego modelu biznesowego w kontekście możliwości poprawy zarówno całego modelu, jak też w odniesieniu do wybranych elementów modelu. Stąd pytania, jakie zarządy i właściciele przedsiębiorstw stale powinni sobie zadawać skupiają się wokół modelu biznesowego, czyli np.:

- czy wartość oferowana klientowi jest nadal tym, czego on oczekuje, czy konkurencja nie dostarcza lepszych rozwiązań?

- czy jest możliwość zaoferowania rozwiązań nowym klientom, wejścia na inne niż dotychczasowe rynki?

- czy istnieje możliwość poprawy efektywności, sprawności, wygody dla klienta $\mathrm{w}$ procesie docierania do niego $\mathrm{z}$ ofertą?

${ }^{8}$ P. Bednarz, Typowe modele biznesowe w nauce zarzadzania [w:] Modele biznesowe, Warszawa 2011, http://www.arch.iped.pl/publikacje/Modele_Biznesowe_Przedsiebiorstw_Tworzonych_na_ Bazie_Szkol_Wyzszych.pdf (dostęp: 12.12.2017 r.), s. 11.

9 M. Sagan, Modele biznesu w epoce Network Economy, „Roczniki Ekonomii i Zarządzania”, t. 5(41)/2013, Lublin 2013, s. 293. 
- w jaki sposób możemy poprawiać satysfakcję klienta? jak sprawić, aby raz pozyskany klient pozostał lojalny?

- czy istnieją możliwości usprawnień w obszarze gospodarowania zasobami, współpracy z kluczowymi partnerami, aby dostarczać klientom określoną wartość poprawiając efektywność finansową podmiotu?

Według J. Schumpetera, model biznesowy powinien być efektem uczenia się ekonomiki klienta, sektora i otoczenia, i powinien cechować się:

- innowacyjnością (względną i bezwzględną; adaptacyjną i kreacyjną),

- rewolucyjnością,

- odpowiednim długodystansowym charakterem,

- elastycznością,

- łatwością w destrukcji (w wychodzeniu) ${ }^{10}$.

Definiowane modelu biznesowego zasadza się na wartościach dla klienta (tabela 1).

Tabela 1. Typy, rodzaje wartości dla klienta i praktyczne przykłady ich definiowania

\begin{tabular}{|c|c|c|}
\hline $\begin{array}{l}\text { Typ war- } \\
\text { tości dla } \\
\text { klienta }\end{array}$ & $\begin{array}{l}\text { Rodzaj wartości } \\
\text { dla klienta }\end{array}$ & Przykłady definiowania wartości dla klienta \\
\hline \multirow{11}{*}{$\begin{array}{l}\text { Wartość } \\
\text { użytkowa }\end{array}$} & $\begin{array}{l}\text { Konkretne cechy } \\
\text { użytkowe }\end{array}$ & $\begin{array}{l}\text { Trwałość, długość eksploatacji, wytrzymałość, moc, ergono- } \\
\text { mia, nacisk itp. }\end{array}$ \\
\hline & $\begin{array}{l}\text { Zaspokojenie } \\
\text { potrzeb użytkowych }\end{array}$ & Wyżynanie, cięcie, prasowanie, kształtowanie itp. \\
\hline & $\begin{array}{l}\text { Zdolność do rozwią- } \\
\text { zywania problemów }\end{array}$ & $\begin{array}{l}\text { Zwiększenie jakości, zwiększenie wytrzymałości, poprawa pa- } \\
\text { rametrów eksploatacyjnych, ułatwienie działania itp. }\end{array}$ \\
\hline & $\begin{array}{l}\text { Budowanie } \\
\text { przewagi nad } \\
\text { konkurentami }\end{array}$ & $\begin{array}{l}\text { Przewaga technologiczna, przewaga wzornicza, przewaga do- } \\
\text { stępności, przewaga kosztowa, przewaga serwisu, przewaga } \\
\text { obsługi klienta }\end{array}$ \\
\hline & $\begin{array}{l}\text { Wykorzystywanie } \\
\text { okazji }\end{array}$ & $\begin{array}{l}\text { Umożliwienie wejścia na nowe rynki, objęcie nowych segmen- } \\
\text { tów, zdobycie nowych kluczowych klientów, stworzenie no- } \\
\text { wych potrzeb, wykreowanie nowych rynków }\end{array}$ \\
\hline & $\begin{array}{l}\text { Oszczędność } \\
\text { kosztów }\end{array}$ & $\begin{array}{l}\text { Obniżka kosztów materiałowych, ludzkich i finansowych; } \\
\text { zmniejszenie zużycia surowców, zmniejszenie zużycia energii, } \\
\text { itp. }\end{array}$ \\
\hline & $\begin{array}{l}\text { Zwiększenie } \\
\text { efektywności }\end{array}$ & $\begin{array}{l}\text { Zwiększenie efektu w jednostce czasu, zwiększenie opłacalno- } \\
\text { ści, zwiększenie efektu na jednostkę nakładu, obniżenie na- } \\
\text { kładu na jednostkę efektu itp. }\end{array}$ \\
\hline & Szybkość & $\begin{array}{l}\text { Szybkość obsługi, szybkość realizacji, skrócenie czasu wyko- } \\
\text { nywania czynności }\end{array}$ \\
\hline & Sprawność & Możliwość liczenia na efekt, niezawodność \\
\hline & Łatwość obsługi & $\begin{array}{l}\text { Ułatwienie obsługi, intuicyjność obsługi, uproszczenie obsługi, } \\
\text { krótkie instrukcje, obsługa sekwencyjna, obsługa jednorazowa }\end{array}$ \\
\hline & $\begin{array}{l}\text { Wiarygodność } \\
\text { informacji }\end{array}$ & $\begin{array}{l}\text { Wzbudzenie zaufania, zbudowanie przekonania o prawdo- } \\
\text { mówności firmy }\end{array}$ \\
\hline
\end{tabular}

${ }^{10}$ J. Schumpeter, Kapitalizm, socjalizm, demokracja, Warszawa 1995, s. 104. 
Tabela 1 (cd.). Typy, rodzaje wartości dla klienta i praktyczne przykłady ich definiowania

\begin{tabular}{|c|c|c|}
\hline $\begin{array}{l}\text { Typ war- } \\
\text { tości dla } \\
\text { klienta }\end{array}$ & $\begin{array}{l}\text { Rodzaj wartości } \\
\text { dla klienta }\end{array}$ & Przykłady definiowania wartości dla klienta \\
\hline & $\begin{array}{l}\text { Inne wartości } \\
\text { użytkowe }\end{array}$ & $\begin{array}{l}\text { Np. możliwość uzyskania osobistych wyjaśnień, porady i kon- } \\
\text { sultacji związanej z wykorzystywaniem danego produktu czy } \\
\text { usługi, terminowość dostawy itp. }\end{array}$ \\
\hline & $\begin{array}{l}\text { Prestiż i reputacja } \\
\text { marki lub przedsię- } \\
\text { biorstwa }\end{array}$ & $\begin{array}{l}\text { Możliwość uzyskania lepszego samopoczucia klienta, który } \\
\text { kupując tego typu produkty czy usługi podnosi swoją samoo- } \\
\text { cenę, możliwość wykorzystania stereotypów związanych z wy- } \\
\text { sokimi markami czy wysoką pozycją przedsiębiorstw }\end{array}$ \\
\hline & $\begin{array}{l}\text { Przynależność } \\
\text { do grupy } \\
\text { użytkowników }\end{array}$ & $\begin{array}{l}\text { Zbudowanie świadomości przynależności do elitarnej grupy } \\
\text { użytkowników, podkreślenie wyjątkowości odbiorcy }\end{array}$ \\
\hline & $\begin{array}{l}\text { Poczucie piękna } \\
\text { i estetyki }\end{array}$ & Zaliczenie klienta do znawców, docenienie jego gustu \\
\hline & $\begin{array}{l}\text { Wartości społeczne } \\
\text { i przyjazność dla } \\
\text { środowiska }\end{array}$ & $\begin{array}{l}\text { Podkreślenie środowiskowej odpowiedzialności klienta, pod- } \\
\text { kreślenie jego nowoczesności }\end{array}$ \\
\hline & $\begin{array}{l}\text { Moda i gust } \\
\text { konsumenta }\end{array}$ & $\begin{array}{l}\text { Podkreślenie dobrego gustu klienta, podkreślenie nowoczesno- } \\
\text { ści i innowacyjności klienta, podkreślenie przynależności do } \\
\text { grupy osób modnych }\end{array}$ \\
\hline & Marka handlowa & $\begin{array}{l}\text { Wykorzystanie siły przyzwyczajenia, wykorzystanie tradycji, } \\
\text { wykorzystanie stereotypów związanych z marką }\end{array}$ \\
\hline & $\begin{array}{l}\text { Możliwość samorea- } \\
\text { lizacji lub zaspoko- } \\
\text { jenia potrzeb ducho- } \\
\text { wych }\end{array}$ & $\begin{array}{l}\text { Produkt czy usługa zaspokajają wyższe potrzeby tych, które je } \\
\text { mają (nie wszyscy mają wyższe potrzeby), kupując produkt } \\
\text { klient zalicza się do elitarnego grona }\end{array}$ \\
\hline & $\begin{array}{l}\text { Inne wartości } \\
\text { emocjonalne }\end{array}$ & $\begin{array}{l}\text { Związane np. z narodowością, regionalizmem, popieraniem lo- } \\
\text { kalności itp. }\end{array}$ \\
\hline
\end{tabular}

Źródło: P. Kulawczuk, Projektowanie modelu biznesowego małej firmy innowacyjnej na podstawie koncepcji Andrewsa 1971) - omówienie wzorca [w:] Modele biznesowe przedsiębiorstw tworzonych na bazie szkót wyższych, red. M. Bąk, P. Kulawczuk, A. Szcześniak, Warszawa 2011, http://www.arch.iped.pl/publikacje/Modele_Biznesowe_Przedsiebiorstw_Tworzonych_na_Bazie_ Szkol_Wyzszych.pdf (dostęp: 12.12.2017 r.), s. 83-84.

Model biznesowy może być traktowany jako narzędzie do kreowania nowych metod prowadzenia działalności gospodarczej, a w ramach tego do reorganizacji wewnętrznych procesów, poszukiwania nowatorskich sposobów sprzedaży lub komunikacji z klientami. Jednakże w przypadku najmniejszych przedsiębiorstw model biznesowy kształtuje się jako całościowy system w sposób niemalże naturalny, dzięki zaangażowaniu, pomysłowości, doświadczeniu samego przedsiębiorcy. Innowacyjny, nietypowy sposób myślenia pozwala na utrzymanie się na rynku, na ekspansję na rynki międzynarodowe i osiągnięcie sukcesu. Ważnym elementem tego modelu we współcześnie działających małych i średnich przedsiębiorstwach są narzędzia informatyczne i komunikatory internetowe. Badania polskich 
naukowców wskazują, ze nawet $90 \%$ małych i średnich przedsiębiorstw wykorzystuje Internet w sposób bierny, zaś $35-50 \%$ tych podmiotów również czynnie ${ }^{11}$. Internet może być wykorzystywany w różnych obszarach działalności firmy i poprzez rozmaite formy aktywności przedsiębiorstw. Według raportu Elektroniczna gospodarka $w$ Polsce ${ }^{12}$ małe i średnie przedsiębiorstwa wykorzystują Internet w następujących funkcjonalnościach: informacyjnej (np. poprzez dostępność do informacji poprzez strony WWW), komunikacyjnej (poczta elektroniczna), marketingowej (prezentacja ofert i reklama w różnej postaci - strony WWW, banery itp.), wspomagającej procesy zarządzania (wynajem oprogramowania, archiwizacja, dostęp do baz danych), wspomagającej wymianę handlową (np. platformy B2B). Na temat wykorzystaniu systemów teleinformatycznych, narzędzi gospodarki elektronicznej prowadzi się wiele badań ${ }^{13}$. Jednakże, jak wykazuje praktyka, nie tylko wykorzystanie narzędzi gospodarki elektronicznej jest elementem kształtującym przemiany modeli biznesowych. Kreatywność przedsiębiorców w obszarze wdrażania innowacyjnych produktów, innowacyjnych technologii, nowych kanałów dystrybucji, sposobów pozyskiwania klientów - przekłada się na dynamiczny rozwój małych i średnich przedsiębiorstw, również w branżach niszowych. Wszystkie wymienione wyżej obszary działalności przedsiębiorstwa - tworząc architekturę systemu jakim jest przedsiębiorstwo stwarzają możliwość kreacji nowatorskich modeli biznesowych, dostosowanych np. do specyficznych warunków działania przedsiębiorstwa.

\section{KREOWANIE MODELU BIZNESOWEGO W BRANŻACH NISZOWYCH NA PRZYKŁADZIE MAŁYCH I ŚREDNICH PRZEDSIĘBIORSTW WOJEWÓDZTWA PODKARPACKIEGO}

Dla prezentacji i analizy modeli biznesowych małych i średnich przedsiębiorstw województwa podkarpackiego wybrano metodologię The Business Model Canvas ${ }^{14}$ opracowaną przez A. Osterwaldera ${ }^{15}$. Zgodnie z przytoczonymi w pierwszej części niniejszego opracowania definicjami, za model biznesowy przyjmuje się „,zestaw elementów i zachodzących między nimi relacji”, które składają się na tzw. logikę biznesową ${ }^{16}$. A. Walczyk ${ }^{17}$ dokonała ciekawego przeglądu czterowymiarowych modeli biznesowych na podstawie prac m.in.

${ }^{11}$ T. Łuczka, Rola Internetu w rozwoju matych i średnich przedsiębiorstw [w:] Mikrofirma 2008 Uwarunkowania rynkowe rozwoju mikro i matych przedsiębiorstw, „Ekonomika i Organizacja Przedsiębiorstwa" 2008, nr specjalny, s. 52-54.

${ }^{12}$ M. Kraska (red.), Elektroniczna gospodarka w Polsce. Raport 2007, Poznań 2008.

${ }^{13}$ E. Wojnicka-Sycz, Narzędzia ICT wspierajace proces innowacyjny, Prace Wydziału Zarządzania Uniwersytetu Gdańskiego, „Zarządzanie i Finanse” 2013/4/1, s. 403-417.

${ }^{14}$ Metodologia ta była już wykorzystywana w badaniach modeli biznesowych polskich przedsiębiorstw przez m.in.: M. Pierścieniak, J. Drzewiecki, A. Równicka, K. Leszczewska i in.

15 A. Osterwalder, Tworzenie modeli..., s. 20-45.

16 A. Ostrwalder, Y. Pigneur, Ch.L. Tuccin, Claryfying Business Models: Origins, Present, and Future of the Concept, "Communications of the Association for Information Systems" 2015, nr 16, 2005/16, s. 18.

17 A. Walczyk, Koncepcja modelu biznesu przedsiębiorstwa działającego w branży odlewniczej, Prace Naukowe Uniwersytetu Ekonomicznego we Wrocławiu nr 475/2017 
Shafera, Smitha, Lindera ${ }^{18}$, Slywotzky, Morrisona, Andelmana ${ }^{19}$ oraz Hamela ${ }^{20}$. Elementy modeli biznesowych ujęte w opracowaniach tych autorów w niektórych obszarach wydają się zbieżne, m.in. kreowanie wartości dla klienta, kluczowe - strategiczne zasoby, czy łączność - komunikacja z klientami. Analizując i porównując z nimi koncepcję Osterwaldera, wydaje się, że w najpełniejszy sposób opisuje ona „filozofię prowadzenia działalności” model biznesu.

Zatem na potrzeby niniejszego artykułu, dla opisu koncepcji biznesowej wraz z jej procesami przyjęto dziewięć obszarów zgodnie z Modelem Biznesowym Canvas, a są nimi: wartość dla klienta, segmenty klientów, kanały dystrybucji, komunikacja z klientami, kluczowe czynności (aktywności), kluczowe zasoby, powiązania partnerskie i kooperacyjne, struktura kosztów, źródła i strumienie przychodów.

Do analizy wybrano przedsiębiorstwa zlokalizowane w województwie podkarpackim. Województwo podkarpackie jest specyficznym regionem. Lokalizacja, charakter regionu, tradycje przyczyniają się do niskiej oceny rozwoju społeczno-gospodarczego w porównaniu z innymi regionami Polski. Z drugiej zaś strony, widoczny jest olbrzymi potencjał ze względu na zasoby turystyczne, przyjazny klimat dla inwestycji, działalność i rozwój klastrów o strategicznym znaczeniu dla rozwoju tej części kraju (działają tu:. Podkarpacki Park Naukowo-Technologiczny Aeropolis oraz szereg innych instytucji otoczenia biznesu, w tym Specjalna Strefa Ekonomiczna, działa również unikalny klaster lotniczy - Stowarzyszenie Dolina Lotnicza). Ważnymi - z punktu widzenia kreowania przyszłego potencjału regionu są wysoko wykwalifikowane i wykształcone zasoby ludzkie. Na terenie województwa podkarpackiego funkcjonuje aktualnie 16 uczelni wyższych, wśród nich największe to Politechnika Rzeszowska im. I. Łukasiewicza oraz Uniwersytet Rzeszowski. W ostatnich latach nastąpił bardzo dynamiczny rozwój w dziedzinie turystyki i usług. Region jest bardzo atrakcyjny turystycznie, ze względu na różnorodność krajobrazu oraz walory historyczne i kulturowe (m.in. dwa parki narodowe: bieszczadzki i magurski oraz kilka parków krajobrazowych, najciekawsze obiekty to: cerkwie - w tym najstarsza w Polsce w Posadzie Rybotyckiej, zespoły pałacowe i zamki - m.in. w Łańcucie, Krasiczynie, a także Muzeum Kopalnictwa Naftowego w Bóbrce). Warto jednakże podkreślić duże zróżnicowanie w rozwoju gospodarczym w układzie subregionalnym co niewątpliwie istotnie wpływa na rozwój społeczny i gospodarczy, a także rozwój przedsiębiorczości. Według raportu PARP województwo podkarpackie cechuje się jednym z najniższych wskaźników przedsiębiorczości na poziomie 23,33 , a liczba działających przedsiębiorstw przypadających na 1000 mieszkańców wynosi $35,97^{21}$.

Charakterystyka regionu skłania do twierdzenia, iż przedsiębiorstwa zlokalizowane na terenie województwa podkarpackiego, ze względu na jego specyfikę, będą często poszukiwały nowych lub niekonwencjonalnych modeli biznesowych, które pozwolą im zaistnieć, przetrwać i odnieść sukces na rynku. Poza tradycyjnymi branżami, segmentami rynku, sposobami sprzedaży, metodami prowadzenia i zarządzania przedsiębiorstwem, coraz częściej

\footnotetext{
${ }^{18}$ S.M. Shafer, H.J. Smith, J.C. Linder, The power of research models, "Business Horizons" 2005, Vol. 48, s. 202.

19 A.J. Slywotzky, D.J. Morisson, B. Andelman, Strefa zysku. Strategiczne modele działalności, Warszawa 2000, s. 367-372.

${ }^{20}$ G. Hamel, Leading the Revolution, Harvard Business School Press 2002, s. 73.

${ }^{21}$ Raport o stanie matych i średnich przedsiębiorstw w Polsce, Warszawa 2017, s. 45-49.
} 
dla uzyskania przewag konkurencyjnych, przedsiębiorcy poszukują niszowych, nietypowych rozwiązań zarówno w obszarze samego produktu, lecz jak się okazuje również w sposobie działania. Wśród przedstawicieli sektora małych i średnich przedsiębiorstw dość często słyszy się opinie o niewystarczającej wiedzy, braku informacji na temat narzędzi wspomagających zarządzanie firmą. Należy jednak podkreślić ich olbrzymie zaangażowanie, a często również „intuicję biznesową”, która pozwala podejmować takie aktywności, które pozwalają na wzrost firmy i odnoszenie sukcesów.

Zamierzeniem autorek jest więc próba uchwycenia wyróżniających cech oraz zmian zachodzących w podejściu przedsiębiorców do prowadzenia działalności gospodarczej, w celu wskazania przemian w modelach biznesu dla trzech podmiotów zaliczanych do sektora małych i średnich przedsiębiorstw zlokalizowanych na terenie województwa podkarpackiego. Każde z nich reprezentuje inną wielkość (mikro, małe i średnie), lecz ich działalność jest prowadzona w branżach niszowych. Ze względu na fakt, iż dwa spośród analizowanych przedsiębiorstw są prowadzone jako działalność osoby fizycznej, a właściciele nie wyrazili zgody na ujawnienie ich danych osobowych - w analizie zdecydowano oznaczyć badane firmy jako: „Przedsiębiorstwo A” - mikro, „Przedsiębiorstwo B” - małe, „Przedsiębiorstwo C" - średnie. Poniżej przedstawiono krótką charakterystykę wybranych do analizy przedsiębiorstw, a następnie dokonano analizy porównawczej tych podmiotów w oparciu o dziewięć elementów Modelu Biznesu Canvas (wyniki analizy przedstawiono w tabeli 2).

„Przedsiębiorstwo A” jest zaliczane do grupy mikroprzedsiębiorstw, zatrudniając jedynie właściciela. Na rynku funkcjonuje od czterech lat i od początku profil działalności jest związany z branżą modelarską. Przedmiotem działalności jest wytwarzanie i sprzedaż produktów niszowych, którymi są poszczególne elementy oraz całe makiety dla kolekcjonerów, muzeów, a także makiety dla dzieci. Firma ma zasięg krajowy, zaś klienci są pozyskiwani przez kontakty w środowisku kolekcjonerskim, natomiast aktualnie przede wszystkim kanałami internetowymi. Właściciel ocenia, iż kluczowymi czynnikami kształtującymi wartość firmy są:

- unikalny i nietypowy asortyment i usługi,

- szybkość i terminowość realizacji zamówień i zleceń,

- duża elastyczność w dostosowaniu się do życzeń i preferencji klientów.

W opinii przedsiębiorcy, na efekty działalności firmy w największym stopniu wpływają wiedza i umiejętności, zaś rozwój przedsiębiorstwa jest uzależniony wyłącznie od zaangażowania właściciela. Ze względu na rosnącą ilość zamówień i problemy lokalowe priorytetem właściciela „Przedsiębiorstwa A” jest budowa magazynu oraz zatrudnienie dwóch pracowników.

„Przedsiębiorstwo B” zaliczane jest do małych przedsiębiorstw. Działa na rynku od ponad dwudziestu lat, jest firmą rodzinną. Aktualnie zatrudnienie wynosi 30 osób. Firma zajmuje się produkcją ozdób choinkowych ręcznie malowanych, które sprzedawane są zarówno w kraju, jak i za granicą. Przedsiębiorca - nestor rodziny - wymieniając główne czynniki kształtujące wartość firmy, podkreślił przede wszystkim kwalifikacje i umiejętności pracowników, co przekłada się na jakość, estetykę i oryginalność produktów. Zwrócił on również uwagę na umiejętne zarządzanie aktywami rzeczowymi i finansowymi oraz dobrą organizację procesów w firmie. W najbliższej przyszłości planowana jest budowa magazynów, pozyskanie nowych odbiorców - zwłaszcza poprzez udoskonalenie systemu 
sprzedaży internetowej, zaś w dłuższej perspektywie - rozbudowa działalności i zmniejszenie kosztów produkcji. Czynnikami sukcesu badanej firmy było zdaniem jej właściciela przede wszystkim pozyskanie klientów zagranicznych oraz wybudowanie filii przedsiębiorstwa.

Tabela 2. Elementy modelu biznesowego dla analizowanych przedsiębiorstw

\begin{tabular}{|c|c|c|c|}
\hline $\begin{array}{c}\text { Elementy modelu } \\
\text { biznesowego } \\
\text { wg A. Osterwaldera }\end{array}$ & Przedsiębiorstwo A & Przedsiębiorstwo B & Przedsiębiorstwo C \\
\hline $\begin{array}{l}\text { Wartość dla klienta } \\
\text { w obszarze } \\
\text { produktów }\end{array}$ & $\begin{array}{l}\text { unikalny, niszowy typ } \\
\text { produktu: } \\
\text { - modele/ makiety/ele- } \\
\text { menty modelarskie - } \\
\text { sprzedaż i usługi w za- } \\
\text { kresie przygotowania } \\
\text { makiet }\end{array}$ & $\begin{array}{l}\text { specyficzny typ produktu } \\
\text { o szczególnym charakte- } \\
\text { rze } \\
\text { - produkcja ozdób choin- } \\
\text { kowych (bombki ręcznie } \\
\text { malowane) } \\
\text { - sezonowość produktu }\end{array}$ & $\begin{array}{l}\text { szczególny produkt } \\
\text { sprzedawany w niety- } \\
\text { powy sposób } \\
\text { - ekologiczne produkty } \\
\text { lokalne (warzywa, } \\
\text { owoce, miody, produkty } \\
\text { zbożowe i inne) } \\
\text { - wody mineralne z wła- } \\
\text { sną marką } \\
\text { - dowóz produktów bez- } \\
\text { pośrednio do klienta }\end{array}$ \\
\hline Segmenty klientów & $\begin{array}{l}\text { specyficzna, niszowa } \\
\text { grupa klientów o ściśle } \\
\text { określonych oczekiwa- } \\
\text { niach co do pro- } \\
\text { duktu/usługi }\end{array}$ & $\begin{array}{l}\text { odbiorcy krajowi } \\
\text { i zagraniczni: sklepy, } \\
\text { hurtownie, indywidualne } \\
\text { zamówienia dla firm }\end{array}$ & $\begin{array}{l}\text { odbiorcy detaliczni pro- } \\
\text { wadzący gospodarstwo } \\
\text { domowe w sposób trady- } \\
\text { cyjny o określonych } \\
\text { oczekiwaniach co do ja- } \\
\text { kości i pochodzenia pro- } \\
\text { duktów spożywczych, } \\
\text { chętnie korzystający z lo- } \\
\text { kalnych, zdrowych, eko- } \\
\text { logicznych produktów }\end{array}$ \\
\hline Kanały dystrybucji & $\begin{array}{l}\text { - bezpośrednie zamówie- } \\
\text { nia elementów modelar- } \\
\text { skich oraz zlecenia wy- } \\
\text { konania makiet zgodnie } \\
\text { z życzeniami klienta } \\
\text { - sprzedaż internetowa } \\
\text { elementów modelarskich }\end{array}$ & $\begin{array}{l}\text { - wypracowana na pod- } \\
\text { stawie doświadczeń wła- } \\
\text { ściciela - „nestora” sieć } \\
\text { dystrybucyjna } \\
\text { - rozbudowana sieć } \\
\text { o nowe rynki w innych } \\
\text { regionach kraju i poza } \\
\text { granicami kraju przez } \\
\text { młodsze pokolenie } \\
\text { (przedsiębiorstwo jest } \\
\text { firmą rodzinną) }\end{array}$ & \multirow{2}{*}{$\begin{array}{l}\text { Komunikacja z klientem } \\
\text { i dystrybucja produktów } \\
\text { jest związana ze szcze- } \\
\text { gólnym sposobem sprze- } \\
\text { daży produktów. Polega } \\
\text { to na dostarczaniu świe- } \\
\text { żych produktów bezpo- } \\
\text { średnio do klienta - spe- } \\
\text { cjalnymi samochodami } \\
\text { dostawczymi wg harmo- } \\
\text { nogramu systematycz- } \\
\text { nych dostaw. Samochody } \\
\text { dostawcze wg określo- } \\
\text { nego terminarza odwie- } \\
\text { dzają poszczególne miej- } \\
\text { sca (dzielnice, ulice, } \\
\text { miejscowości itd.) mając } \\
\text { przygotowane produkty } \\
\text { zamówiono w poprzed- } \\
\text { nich wizytach lub zamó- } \\
\text { wione drogą internetową }\end{array}$} \\
\hline $\begin{array}{l}\text { Komunikacja } \\
\text { z klientami }\end{array}$ & $\begin{array}{l}\text { - kanały komunikacji - } \\
\text { wykształcone w drodze } \\
\text { przekazywania informa- } \\
\text { cji pomiędzy klientami } \\
\text { tej wąskiej i specyficznej } \\
\text { grupy } \\
\text { - uruchomienie sklepu } \\
\text { internetowego }\end{array}$ & $\begin{array}{l}\text { tradycyjne kanały komu- } \\
\text { nikacji na podstawie wy- } \\
\text { pracowanej sieci odbior- } \\
\text { ców } \\
\text {-uruchomienie sklepu in- } \\
\text { ternetowego }\end{array}$ & \\
\hline
\end{tabular}


Tabela 2 (cd.). Elementy modelu biznesowego dla analizowanych przedsiębiorstw

\begin{tabular}{|c|c|c|c|}
\hline $\begin{array}{c}\text { Elementy modelu } \\
\text { biznesowego } \\
\text { wg A. Osterwaldera }\end{array}$ & Przedsiębiorstwo A & Przedsiębiorstwo B & Przedsiębiorstwo C \\
\hline $\begin{array}{l}\text { Kluczowe czynności } \\
\text { (aktywności) }\end{array}$ & $\begin{array}{l}\text { - pełna elastyczność } \\
\text { w dostosowaniu się do } \\
\text { wymagań klienta } \\
\text { - rozbudowa oferty w za- } \\
\text { kresie produkcji pojedyn- } \\
\text { czych elementów mode- } \\
\text { larskich }\end{array}$ & $\begin{array}{l}\text { - kreacja nowych modeli } \\
\text { produktów w odmiennej } \\
\text { (nowatorskiej) estetyce } \\
\text { - przełamywanie stereo- } \\
\text { typów dotyczących } \\
\text { kształtów i form ozdób } \\
\text { choinkowych } \\
\text { - produkcja ozdób na po- } \\
\text { trzeby innych świąt }\end{array}$ & $\begin{array}{l}\text { - poszerzanie asorty- } \\
\text { mentu sprzedawanych } \\
\text { produktów lokalnych } \\
\text { - ustawiczne rozszerzanie } \\
\text { rynku (również/zwłasz- } \\
\text { cza pod względem geo- } \\
\text { graficznym) }\end{array}$ \\
\hline Kluczowe zasoby & $\begin{array}{l}\text { - wiedza, kreatywność } \\
\text { i umiejętności przedsię- } \\
\text { biorcy }\end{array}$ & $\begin{array}{l}\text { - doświadczenie, wiedza } \\
\text { i kreatywność właścicieli } \\
\text { i pracowników firmy } \\
\text {-tradycja }\end{array}$ & $\begin{array}{l}\text { - zdrowy, ekologiczny } \\
\text { produkt lokalny } \\
\text { - dostępność wód mine- } \\
\text { ralnych i źródlanych } \\
\text { - specyficzny/ nietypowy } \\
\text { model sprzedaży }\end{array}$ \\
\hline $\begin{array}{l}\text { Powiązania partner- } \\
\text { skie, kooperacyjne } \\
\text { (sieciowe) }\end{array}$ & $\begin{array}{l}\text { - produkcja własna } \\
\text { i sprzedaż internetowa } \\
\text { wybranych elementów, } \\
\text { - współpraca z producen- } \\
\text { tami elementów modelar- } \\
\text { skich nie wytwarzanych } \\
\text { przez badany podmiot }\end{array}$ & $\begin{array}{l}\text { - na poziomie poddo- } \\
\text { stawców surowców } \\
\text { i materiałów niezbęd- } \\
\text { nych w procesie produk- } \\
\text { cyjnym - sieć wypraco- } \\
\text { wana na podstawie do- } \\
\text { tychczasowych doświad- } \\
\text { czeń właściciela } \\
\text { - na poziomie odbiorców } \\
\text { - także wypracowana } \\
\text { baza wynikająca z do- } \\
\text { świadczeń właściciela, } \\
\text { a także nowa baza usta- } \\
\text { wicznie rozszerzana } \\
\text { dzięki aktywności } \\
\text { w Internecie }\end{array}$ & $\begin{array}{l}\text { - zdefiniowana, ale usta- } \\
\text { wicznie poszerzająca się } \\
\text { baza poddostawców } \\
\text { i odbiorców }\end{array}$ \\
\hline Struktura kosztów & $\begin{array}{l}\text {-największy udział } \\
\text { w kosztach ogółem mają } \\
\text { koszty wytwarzania ele- } \\
\text { mentów modelarskich } \\
\text { oraz koszty magazyno- } \\
\text { wania }\end{array}$ & $\begin{array}{l}\text { - największy udział } \\
\text { w kosztach ogółem mają } \\
\text { koszty procesów produk- } \\
\text { cyjnych - warto przy tym } \\
\text { podkreślić specyfikę pro- } \\
\text { dukcji (wydmuchanie } \\
\text { szklanych form ozdób, } \\
\text { ręczne malowanie ozdób } \\
\text { choinkowych) }\end{array}$ & $\begin{array}{l}\text { - koszty w prowadzonym } \\
\text { rachunku kosztów SA } \\
\text { ujmowane wg ich rodza- } \\
\text { jów. } \\
\text { - dużą ich część stano- } \\
\text { wią koszty zakupu pro- } \\
\text { duktów lokalnych, } \\
\text { koszty butelkowania wód } \\
\text { mineralnych, koszty } \\
\text { transportu }\end{array}$ \\
\hline
\end{tabular}


Tabela 2 (cd.). Elementy modelu biznesowego dla analizowanych przedsiębiorstw

\begin{tabular}{|c|c|c|c|}
\hline $\begin{array}{c}\text { Elementy modelu } \\
\text { biznesowego } \\
\text { wg A. Osterwaldera }\end{array}$ & Przedsiębiorstwo A & Przedsiębiorstwo B & Przedsiębiorstwo C \\
\hline Struktura kosztów & \multirow{2}{*}{$\begin{array}{l}\text { - przedsiębiorca prowa- } \\
\text { dzi uproszczoną księgo- } \\
\text { wość w oparciu o podat- } \\
\text { kową książkę przycho- } \\
\text { dów i rozchodów } \\
\text { - ta forma księgowa wy- } \\
\text { daje się wystarczająca na } \\
\text { aktualnym etapie roz- } \\
\text { woju firmy, jednakże } \\
\text { znacząco ogranicza moż- } \\
\text { liwości głębszej analizy } \\
\text { i przeprowadzenia ra- } \\
\text { chunku efektywności } \\
\text { i rentowności }\end{array}$} & \multirow{2}{*}{$\begin{array}{l}\text { - przedsiębiorstwo pro- } \\
\text { wadzi księgi rachunkowe } \\
\text { zgodnie z ustawą } \\
\text { o rachunkowości } \\
\text { - koszty ujmowane są wg } \\
\text { rodzaju, porównawczy } \\
\text { wariant ustalania wyniku } \\
\text { finansowego } \\
\text { - właściciel na podstawie } \\
\text { gromadzonych danych } \\
\text { samodzielnie przeprowa- } \\
\text { dza najprostsze wylicze- } \\
\text { nia dla bieżącej oceny } \\
\text { kondycji i rentowności } \\
\text { firmy }\end{array}$} & \multirow{2}{*}{$\begin{array}{l}\text { - przedsiębiorstwo pro- } \\
\text { wadzi księgi rachunkowe } \\
\text { zgodnie z ustawą } \\
\text { o rachunkowości } \\
\text { - koszty ujmowane są wg } \\
\text { rodzaju, porównawczy } \\
\text { wariant ustalania wyniku } \\
\text { finansowego } \\
\text { - zarządzający wraz z ko- } \\
\text { mórką finansowo-księ- } \\
\text { gową systematycznie } \\
\text { prowadzą analizę ren- } \\
\text { towności sprzedaży } \\
\text { i oceny kondycji finanso- } \\
\text { wej spółki }\end{array}$} \\
\hline \multirow[b]{2}{*}{$\begin{array}{l}\text { Źródła, strumienie } \\
\text { przychodów }\end{array}$} & & & \\
\hline & $\begin{array}{l}\text { - przychody ze sprzedaży } \\
\text { internetowej } \\
\text { - przychody z indywidu- } \\
\text { alnych zamówień reali- } \\
\text { zowanych na zlecenie } \\
\text { klientów }\end{array}$ & $\begin{array}{l}\text { - przychody ze sprzedaży } \\
\text { produktów stałym i no- } \\
\text { wym odbiorcom } \\
\text { - przychody z indywidu- } \\
\text { alnych zamówień reali- } \\
\text { zowanych np. na zlecenie } \\
\text { firm i instytucji }\end{array}$ & $\begin{array}{l}\text { - przychody ze sprzedaży } \\
\text { produktów i towarów na } \\
\text { podstawie zdefiniowanej } \\
\text { i rozbudowywanej sieci } \\
\text { odbiorców wg ustalo- } \\
\text { nego harmonogramu }\end{array}$ \\
\hline
\end{tabular}

Źródło: opracowanie własne na podstawie materiałów uzyskanych od badanych podmiotów.

„Przedsiębiorstwo C” reprezentuje grupę średnich przedsiębiorstw. Funkcjonuje od ponad dwudziestu lat i aktualnie ma formę spółki akcyjnej. Przedsiębiorstwo zatrudnia ponad 150 osób, a działalność koncentruje się na branży spożywczej. Zasięg, ze względu na specyfikę sprzedawanych towarów, jak i sam sposób docierania do klienta, jest ograniczony do regionu Polski południowo-wschodniej (województwa: podkarpackie, lubelskie, świętokrzyskie, małopolskie). Przedstawiciele badanego podmiotu podkreślają, że na wartość ich firmy wpływają przede wszystkim: identyfikowalna marka produktów, zdefiniowana sieć stałych odbiorców, odpowiednia baza (w sensie materialnym i niematerialnym) kształtująca biznes oraz dopracowana logistyka. Przyszłe cele, które stawia sobie przedsiębiorstwo to ustawiczna dbałość o dobrą kondycję floty transportowej, uruchomienie przetwórstwa rolno-spożywczego pod własną marką, działalność edukacyjna dotycząca ekologii. Na sukces firmy, zdaniem przedstawicieli badanego podmiotu, miały wpływ przede wszystkim: pomysł, dbałość o sieć stałych klientów, poszerzanie asortymentu oraz konsekwencja i terminowość w realizacji harmonogramu dostaw towarów i produktów. Istotne znaczenie w tym względzie ma doświadczenie i umiejętności pracowników zarządu i średniego szczebla zarządzania. 


\section{ZAKOŃCZENIE}

Podsumowując, bazując na przeglądzie literatury w zakresie znaczenia modeli biznesowych i biorąc pod uwagę zaprezentowane przykłady - można sformułować dwa podstawowe wnioski oraz postulowane kierunki zmian tychże modeli biznesowych w polskich przedsiębiorstwach. Kluczowym wyzwaniem wydaje się skoncentrowanie firm na jasno zdefiniowanych segmentach klientów oraz poprawna identyfikacja wartości dla klienta. Jak wynika z doświadczeń przedsiębiorców, to właśnie koncentracja na oczekiwaniach klientów oraz pełna elastyczność w dostosowywaniu się do jego potrzeb, przyczyniły się do wykreowania stosowanych modeli biznesowych i sukcesu badanych podmiotów. Równie istotnym z punktu widzenia wybranych do analizy przedsiębiorstw, wydaje się znalezienie odpowiedniej grupy docelowej i produktu, które stałyby się znaczącą przewagą konkurencyjną - zwłaszcza w przypadku firm działających w regionach słabiej rozwiniętych.

Niewątpliwie, studia literatury jak i przeprowadzona analiza przypadków, skłaniają do stwierdzenia, iż modele biznesowe ułatwiają podejmowanie strategicznych decyzji zarządzającym przedsiębiorstwami i są użyteczne zarówno w małych, jak i dużych przedsiębiorstwach. Z kolei wykorzystywanie modeli biznesowych w bieżącym zarządzaniu pozwala odnajdywać nisze rynkowe i wzmacniać pozycję konkurencyjną firmy poprzez m.in. dywersyfikację działalności, wchodzenie na nowe rynki, znajdywanie nowych zastosowań dla posiadanych produktów, optymalizację zarządzania dostępnymi zasobami i procesami itp.

\section{LITERATURA}

1. Afuah A., Tucci Ch.L., Biznes internetowy - strategie i modele, Oficyna Ekonomiczna, Kraków 2003.

2. Arend R., The business model: Present and future - beyond a skeumorph, "Strategic Organisation" 2013, 11(4).

3. Baden-Fuller Ch., Mangematin V, Business models: A challenging agenda, "Strategic Organisation" 2013, 11(4).

4. Bednarz P., Typowe modele biznesowe w nauce zarzadzania [w:] Modele biznesowe przedsiębiorstw tworzonych na bazie szkół wyższych, red. M. Bąk, P. Kulawczuk, A. Szcześniak, Instytut Badań nad Demokracją i Przedsiębiorstwem Prywatnym, Regionalna Izba Gospodarcza w Katowicach, Przez Naukę do Biznesu, Warszawa 2011.

5. Bytniewski A. (red.), Systemy informatyczne a rozwój społeczeństwa informacyjnego, e-book Wydawnictwo Uniwersytetu Ekonomicznego we Wrocławiu, 2015.

6. Bytniewski A., Hernes M., Technologie informacyjne jako czynnik rozwoju nowych funkcjonalności zintegrowanych systemów zarządzania w ramach koncepcji big management, Studia Ekonomiczne. Zeszyty Naukowe Uniwersytetu Ekonomicznego w Katowicach nr 341/2017.

7. Chesbrough H., Rosenbloom R.S., The role of the business model in capturing value from innovation: evidence from XEROX Corporation's technology spin-off companies, "Industrial and Corporate Change" 2002, 11(3).

8. Demil B., Lecocq X. Business model evolution: In search of dynamic consistency, "Long Range Planning" 2010, Vol. 43.

9. De Wit B., Meyer R., Synteza strategii, PWE, Warszawa 2007.

10. Dobbs R., Manyika J., Woetzel J., No Ordinary Disruption: The Four Global Forces Breaking All the Trends, PublicAffairs, New York 2015. 
11. Drucker P.F., Zarzadzanie w czasach burzliwych, „Nowoczesność Czytelnik”, Warszawa 1995.

12. Hamel G., Leading the Revolution, Harvard Business School Press 2002.

13. Hedman J., Kalling T., The business model concept: theoretical underpinnings and empirical illustrations, "European Journal of Information Systems" 2010, Vol. 12.

14. Johnson M.W., Seizing the white space: Business model innovation for growth and renewal, Harvard Business School Publishing, Boston 2010.

15. Johnson M.W., Christensen C., Reinventing your business model, "Harvard Business Review” 2008, 86(12).

16. Kardas M., Pojęcia i typy modeli biznesu, w: Zarzadzanie, organizacje i organizowanie przeglad perspektyw teoretycznych, red. K. Klincewicz, Wydawnictwo Naukowe Wydziału Zarządzania Uniwersytetu Warszawskiego, Warszawa 2016.

17. Koźmiński A.K., Zarządzanie w warunkach niepewności. Podręcznik dla zaawansowanych, Wydawnictwo Naukowe PWN, Warszawa 2004.

18. Kraska M. (red.), Elektroniczna gospodarka w Polsce. Raport 2007, Biblioteka Logistyka, Poznań 2008.

19. Łuczka T., Rola Internetu $w$ rozwoju matych i średnich przedsiębiorstw [w:] Mikrofirma 2008 - Uwarunkowania rynkowe rozwoju mikro i matych przedsiębiorstw, ,Ekonomika i Organizacja Przedsiębiorstwa" 2008, nr specjalny.

20. Malanowska I., Koliński A., Wykorzystanie narzędzi gospodarki elektronicznej w działalności przedsiębiorstw z sektora MSP, E-MENTOR nr 2(29)/2009.

21. Magretta J., Why business models matter?, "Harvard Business Review" 2002, 80(5).

22. Michniewska K., Rola ekonomii wspótdzielonej w dochodzeniu do celów środowiskowych Unii Europejskiej - nowe modele biznesowe $w$ domykaniu pętli tańcucha dostaw (SSC/CLSC)", Logistyka Odzysku nr 3/2016 (20).

23. Morris M., Schindehutte M., Allen J., The entrepreneur's business model: toward a unified perspective, "Journal of Business Research" 2005, Vol. 58.

24. Obłój K., Tworzywa skutecznych strategii, PWE, Warszawa 2002.

25. Osterwalder A., Pigneur Y., Tworzenie modeli biznesowych. Podręcznik wizjonera, Wydawnictwo Helion, Gliwice 2013.

26. Penc J., Menedżer $w$ działaniu, t. 2: Podejmowanie najlepszych decyzji, CH Beck, Warszawa 2003.

27. Porter M., What is Strategy?, „Harvard Business Review” November-December 1996.

28. Porter M., Strategy and the Internet, "Harvard Business Review", March 2001.

29. Raport o stanie matych i średnich przedsiębiorstw w Polsce, PARP, Warszawa 2017.

30. Sagan M., Modele biznesu w epoce Network Economy, „Roczniki Ekonomii i Zarządzania” t. 5(41)/2013, Towarzystwo Naukowe Katolickiego Uniwersytetu Lubelskiego Jana Pawła II, Lublin 2013.

31. Schumpeter J., Kapitalizm, socjalizm, demokracja, PWN Warszawa 1995.

32. Shafer S.M., Smith H.J., Linder J.C., The power of research models, "Business Horizons" 2005, Vol. 48.

33. Shaughnessy H., Harnessing platform-based business models to power disruptive innovation, Strategy \& Leadership, 44(5) 2016.

34. Slywotzky A.J., Morisson D.J., Andelman B., Strefa zysku. Strategiczne modele działalności, PWE, Warszawa 2000. 
35. Sobinska M., Innowacyjne modele biznesu dla IT-wyzwania i perspektywy rozwoju, Informatyka ekonomiczna, 1(31) 2014.

36. Szpringer W., Innowacyjne modele e-biznesu. Aspekty instytucjonalne, Difin, Warszawa 2012.

37. Teece D.J., Business model, business strategy and innovation, "Long Range Planning" 2010, Vol. 43.

38. Timmers R., Business models for electronic markets, "Electronic Markets" 1998, 8(2)

39. Walczyk A., Koncepcja modelu biznesu przedsiębiorstwa działajacego $w$ branży odlewni$c z e j$, „Prace Naukowe Uniwersytetu Ekonomicznego we Wrocławiu” nr 475/2017.

40. Wielki J., Internet rzeczy i jego wptyw na modele biznesowe wspótczesnych organizacji gospodarczych, Studia Ekonomiczne, Zeszyty Naukowe Uniwersytetu Ekonomicznego w Katowicach, $\mathrm{nr}$ 281, 2016.

41. Wojnicka-Sycz E., Narzędzia ICT wspierajace proces innowacyjny, „Prace Wydziału Zarządzania Uniwersytetu Gdańskiego, Zarządzanie i Finanse”2013/4/1.

42. Wójcik D., Gospodarka wspótdzielenia a gospodarka doznań w sektorze turystycznym, w: Organizacja w sieci relacji, red. S. Lachiewicz, A. Zakrzewska-Bielawska, Wydawnictwo Politechniki Łódzkiej, Łódź 2017.

43. Wixom B., Watson H., The BI - based organization, "International Journal of Business Intelligence Research” 2010, No. 1.

44. Zott Ch., Amit R., The business model: A theoretically anchored robust construct for strategic analysis, "Strategic Organisation" 2013, Vol. 4.

45. Zott Ch., Amit R., Massa L., The business model: Recent developments and future research, "Journal of Management" 2011, Vol. 37.

\section{NETOGRAFIA}

1. Kulawczuk P., Projektowanie modelu biznesowego matej firmy innowacyjnej na podstawie koncepcji Andrewsa 1971) - omówienie wzorca [w:] Modele biznesowe przedsiębiorstw tworzonych na bazie szkót wyższych, red. M. Bąk, P. Kulawczuk, A. Szcześniak, Instytut Badań nad Demokracją i Przedsiębiorstwem Prywatnym, Regionalna Izba Gospodarcza w Katowicach, Przez Naukę do Biznesu, Warszawa 2011, http://www.arch.iped.pl/publikacje/Modele_Biznesowe_Przedsiebiorstw_Tworzonych_na_Bazie_Szkol_Wyzszych.pdf (dostęp: 23.09.2018 r.).

2. Lund D., MacGillivray C., Turner V., Morales M., Worldwide and Regional Internet of Things (IoT) 2014-2020. Forecast: A Virtuous Circle of Proven Value and Demand, IDC 2014, s. 4, http://branden.biz/wp-content/uploads/2017/06/IoT-worldwide_regional_20142020-forecast.pdf (dostęp: 23.09.2018 r.).

3. Mettler A., Williams A.D., The Rise of the MicrO-Multinational: How Freelancers and Technology-Savyy Startu-Ups Are Driving Growth, Jobs and Innovation, Lisbon: Lisbon Council Policy Brief, http://www.lisboncouncil.net/publication/publication/67-the-rise-of-the-micromultinational-how-freelancers-and-technology-savvy-start-ups-are-driving-growth-jobsand-innovation.html (dostęp: 23.09.2018 r.).

4. Skirski P., Nowe modele biznesu wkrótce zmieniq sposób walki o klientów, Rzeczpospolita, 23.03.2016, http://www.rp.pl/Opinie/303239821-Nowe-modele-biznesu-wkrotce-zmieniasposob-walki-o-klientow.html, (dostęp: 23.09.2018 r.).

5. Świderek T., Blockchain zmienia biznes, 19.12.2017, https://www.obserwatorfinansowy.pl/tematyka/makroekonomia/blockchain-zmienia-biznes/ (dostęp: 23.09.2018 r.). 
6. Waszczuk P., Chmura motorem zmian biznesowych i nowych rodzajów ustug, 13.12.2017, https://itwiz.pl/chmura-motorem-zmian-biznesowych-nowych-rodzajow-uslug/ (dostęp: 23. $09.2018 \mathrm{r}$.).

\section{CHALLENGES AND CHANGES IN CREATING BUSINESS MODELS BY POLISH ENTREPRENEURS AND GROWTH PROCESSES OF SMALL AND MEDIUM ENTERPRISES}

Business models are a relatively new tool intensively popularized both in science and business practice of enterprises. Experience shows that their use in company management affects the growth and competitive position of entities. A business model can also be treated as a tool used to create new business methods, and thus to reorganize internal processes, search for innovative ways of selling or communicating with customers. In the case of the smallest enterprises, the business model is shaped as a whole system in an almost natural way, mainly due to the commitment, ingenuity and experience of the entrepreneur himself. Business models are therefore treated as a simple tool that allows to achieve measurable benefits for both small and large enterprises. They facilitate making strategic decisions and support the ongoing management of the company. They allow finding market niches and strengthening the company's competitive position through, among others, diversification of activities, entering new markets, finding new applications for your products, optimizing the management of available resources and processes, etc. Business modeling includes defining the areas of the company's operations, starting from internal processes and ending with customer values.

The article analyzes specific features of business models by referring them to selected enterprises included in the group of micro, small and medium-sized enterprises operating in a specific environment and in the so-called niche industries. The authors presented untypical solutions of business models used by entrepreneurs for the survival and growth of the company.

Keywords: business models, case analysis, company growth, small and medium enterprises.

DOI: $10.7862 /$ rz.2018.hss.42

Przestano do redakcji: styczeń $2018 r$.

Przyjęto do druku: wrzesień 2018 r. 